\title{
Analyzing science communication through the lens of communication science: reviewing the empirical evidence
}

Schäfer, Mike S ; Kessler, Sabrina Heike ; Fähnrich, Birte

\begin{abstract}
From the 1960s onwards, communication scientists have analyzed science communication. This article provides an overview of the empirical evidence that this research has generated. First, it describes the structures of the research field based on available meta-analyses. Then, it describes what is known about the communicators of science (such as scientists, journalists, PR experts, NGOs, and others) and about the portrayals of science in news media as well as online and in social media, and examines what is known about the uses and effects of science communication. For each of these subfields, the questions in focus, typical theoretical approaches, main results, and gaps are identified and reflected upon. In addition, the article identifies research gaps and potential avenues for future research.
\end{abstract}

DOI: https://doi.org/10.1515/9783110255522-004

Posted at the Zurich Open Repository and Archive, University of Zurich

ZORA URL: https://doi.org/10.5167/uzh-186388

Book Section

Published Version

Originally published at:

Schäfer, Mike S; Kessler, Sabrina Heike; Fähnrich, Birte (2019). Analyzing science communication through the lens of communication science: reviewing the empirical evidence. In: Leßmöllmann, Annette; Dascal, Marcelo; Gloning, Thomas. Science communication. Berlin: De Gruyter, 77-104.

DOI: https://doi.org/10.1515/9783110255522-004 


\title{
4 Analyzing science communication through the lens of communication science: Reviewing the empirical evidence
}

\begin{abstract}
From the 1960s onwards, communication scientists have analyzed science communication. This article provides an overview of the empirical evidence that this research has generated. First, it describes the structures of the research field based on available meta-analyses. Then, it describes what is known about the communicators of science (such as scientists, journalists, PR experts, NGOs, and others) and about the portrayals of science in news media as well as online and in social media, and examines what is known about the uses and effects of science communication. For each of these subfields, the questions in focus, typical theoretical approaches, main results, and gaps are identified and reflected upon. In addition, the article identifies research gaps and potential avenues for future research.
\end{abstract}

Keywords: science communication - science communicators - content analysis media use - media effects - communication science - literature review

\section{Introduction}

Science communication encompasses all communication focused on science, scientific work, and its results (cf. Bubela et al. 2009; Bucchi and Trench 2014; Schäfer, Kristiansen, and Bonfadelli 2015). This includes the communication of scientific knowledge to non-scientists, public communication and dialogue about science and its ethical, societal, or political implications, and direct communication between scientists and various publics (Kahan, Scheufele, and Jamieson 2017; Trench and Bucchi 2010).

This broad understanding has developed over several decades and was associated with the evolution of different paradigms of science communication (e.g., Akin and Scheufele 2017; cf. Schmidt-Petri and Bürger in this volume). The debate started with the deficit model and concepts of scientific literacy but shifted to the paradigm of public understanding of science and further from mere communication to a dialogue between science and society, toward the science in society and public engagement with science models (Bucchi and Trench 2014). The deficit model was developed in the 1980s. It assumed that people's attitudes about science were strongly tied to their knowledge about science, i.e., their scientific literacy, and, therefore, saw science communication as an instrument to transfer scientific knowledge to non-scientists. Accordingly, research on science communication in this period focused on the effi-

https://doi.org/10.1515/9783110255522-004 
ciency of information transfer from scientists to laypeople. Later, the focus shifted to public engagement with science models in which non-scientists were seen as equal partners in science and, as a result, were encouraged to participate in science debates and policy formation (Bubela et al. 2009). Recently, Akin and Scheufele (2017) promoted a third model, focusing on science communication in context. They examined a cross-section of public stakeholders and argued that the framework corresponds to an era of public communication in modern democracies in which science communication is shaped by its societal and political environments (see Chapter 5 , this volume).

Associated with the three models were different objectives of science communication. Early on, knowledge transfer was seen as paramount in educating the population, increasing their decision-making power concerning science and science-based innovations. Since then, establishing a dialogue between scientists and society and enabling participation of non-scientists has become an important objective of science communication (Akin and Scheufele 2017). In recent years, building the legitimation of science and its protagonists has become another major aim of science communication. Particularly regarding strategic communication from scientific institutions and individual scientists, the need to legitimize themselves has become more important in recent years (e.g. Weingart 2005).

The importance of science communication not only for the scientific community, but also for society and individuals, has been widely acknowledged (Bubela et al. 2009; Fischhoff and Scheufele 2013). Analyses of science communication from the social sciences and from communication science in particular emerged from the late 1960s onwards, at the intersection of science education, social studies in science, mass communication, museology, etc. (Trench and Bucchi 2010). It aimed to understand the underlying mechanisms, structures, and effects of science communication, and in doing so produced a large number of empirical studies on the communicators, content, and impact of science communication.

The present article provides an overview of these empirical studies. It proceeds in five steps: First, it describes the structures of the research field itself, based on available meta-analyses (section 2). Second, it focuses on studies of the communicators of science communication (section 3). Third, it provides content analyses within science communication (section 4). Fourth, it examines studies on the uses and effects of science communication (section 5). Fifth, it identifies research gaps in this study and offers possible perspectives from which to launch future research (section 6). 


\section{The meta-perspective: Empirical analyses of the research field itself}

Meta-analyses and literature reviews have provided overviews of the field, indicating several trends (e. g., Bucchi and Trench 2014; Guenther and Joubert 2017; Kahan, Scheufele, and Jamieson 2017; Rauchfleisch and Schäfer 2018; Schäfer 2012b; Trench et al. 2014).

On the one hand, they show that the field has grown significantly in recent decades, visible, for example, through the rising number of publications on the issue. Between 1979 and 2016, the main journals of the field - Science Communication (SC), Journal of Science Communication (JCOM), and Public Understanding of Science (PUS) - have provided a steady increase in output (Guenther and Joubert 2017), and publications on science communication have increased in general as well (Schäfer 2012b) from the 1960s onward.

On the other hand, meta-analyses have repeatedly shown that the field has diversified in several ways. First, it has internationalized. Most research into science communication has come, and still comes, from predominantly Western, English-speaking countries, with the US and UK being analyzed most often and most intensely (see Guenther and Joubert 2017). However, science communication has been slowly shifting toward a more international scope (Schäfer 2012b). Second, the field has become more diverse in its objects. Studies in the field have not only analyzed communication in traditional media (TV and, in particular, print) more, but also in online media and social media (Metag 2017; Schäfer 2017b). Third, the research field has been institutionalized, which is visible, for example, in the emergence of scientific associations and working groups devoted to science communication in university chairs, introductory textbooks, and specific journals (e.g. Gascoigne et al. 2010; Rauchfleisch and Schäfer 2018). Fourth, the scientific disciplines analyzed by these studies have changed over time. Overall, research was and is still biased toward the natural sciences, specifically biosciences and medicine (Schäfer 2012b). However, in recent years, the social sciences and humanities have come into view more (Cassidy 2005; Summ and Volpers 2016). Fifth, meta-analyses have shown that researchers in the field increasingly employ a variety of research strategies and methods: longitudinal studies, studies that compare different media outlets, and temporal, or cross-media comparisons, in addition to applying contextual information to their respective findings (Schäfer 2012b). Table 1 summarizes these diverse research perspectives. 
Tab. 1: Overview of core perspectives, questions, approaches, and results of empirical analyses of science communication

\begin{tabular}{|c|c|c|c|}
\hline & $\begin{array}{l}\text { Analyses of communica- } \\
\text { tors in science communi- } \\
\text { cation }\end{array}$ & $\begin{array}{l}\text { Analyses of science } \\
\text { communication content }\end{array}$ & $\begin{array}{l}\text { Analyses of use } \\
\text { and effects of science } \\
\text { communication }\end{array}$ \\
\hline $\begin{array}{l}\text { Main } \\
\text { questions }\end{array}$ & $\begin{array}{l}\text { Actors involved in public } \\
\text { communication of sci- } \\
\text { ence, especially science } \\
\text { journalists, science organ- } \\
\text { izations, and alterna- } \\
\text { tive-science communica- } \\
\text { tors such as NGOs, think } \\
\text { tanks, etc., who deal with } \\
\text { questions of development } \\
\text { of the professional fields, } \\
\text { institutionalization of the } \\
\text { communication function } \\
\text { within science organi- } \\
\text { zations, roles of certain } \\
\text { speakers, and objectives } \\
\text { and strategies of science } \\
\text { communicators }\end{array}$ & $\begin{array}{l}\text { Overall amount of scien- } \\
\text { tific content in media, } \\
\text { media characterizations } \\
\text { of science and its protag- } \\
\text { onists, accuracy of report- } \\
\text { ing measured by scientific } \\
\text { standards, and framing of } \\
\text { science }\end{array}$ & $\begin{array}{l}\text { What information people } \\
\text { use regarding scientific } \\
\text { topics, through which } \\
\text { media they acquire this } \\
\text { information, and how this } \\
\text { usage affects people's } \\
\text { knowledge about science, } \\
\text { science-related attitudes, } \\
\text { interests, beliefs, and } \\
\text { trust, and on a macro-level } \\
\text { how public opinion is } \\
\text { affected }\end{array}$ \\
\hline $\begin{array}{l}\text { Typical } \\
\text { theoretical } \\
\text { approaches }\end{array}$ & $\begin{array}{l}\text { Heterogeneous } \\
\text { approaches from journal- } \\
\text { ism and organizational } \\
\text { communication/PR stud- } \\
\text { ies, as well as basic theo- } \\
\text { ries from social sciences, } \\
\text { such as role theory, news } \\
\text { value theory, and framing }\end{array}$ & $\begin{array}{l}\text { Wide range of theoretical } \\
\text { approaches, such as pub- } \\
\text { lic-sphere theory, framing } \\
\text { theory, and news-bias } \\
\text { theory }\end{array}$ & $\begin{array}{l}\text { Theories mostly on a } \\
\text { macro- or micro-level } \\
\text { concerning a range of } \\
\text { disciplines, including } \\
\text { psychology, pedagogy, } \\
\text { sociology, and communi- } \\
\text { cation science }\end{array}$ \\
\hline $\begin{array}{l}\text { Typical } \\
\text { methods }\end{array}$ & $\begin{array}{l}\text { Mainly survey research } \\
\text { and content analysis, } \\
\text { qualitative approaches } \\
\text { focusing on different } \\
\text { interview formats, and a } \\
\text { large share of single- } \\
\text { case studies }\end{array}$ & $\begin{array}{l}\text { Quantitative or qualitative } \\
\text { content analyses, variants } \\
\text { of discourse analysis }\end{array}$ & $\begin{array}{l}\text { Standardized methods, } \\
\text { particularly } \\
\text { representative surveys } \\
\text { and experiments; more } \\
\text { recently, online research }\end{array}$ \\
\hline
\end{tabular}


Tab. 1: (continued)

\begin{tabular}{|c|c|c|c|}
\hline & $\begin{array}{l}\text { Analyses of communica- } \\
\text { tors in science communi- } \\
\text { cation }\end{array}$ & $\begin{array}{l}\text { Analyses of science } \\
\text { communication content }\end{array}$ & $\begin{array}{l}\text { Analyses of use } \\
\text { and effects of science } \\
\text { communication }\end{array}$ \\
\hline $\begin{array}{l}\text { Main } \\
\text { results }\end{array}$ & $\begin{array}{l}\text { Science journalism is an } \\
\text { institutionalized field of } \\
\text { journalism in many coun- } \\
\text { tries, but organizational } \\
\text { science communication } \\
\text { is growing and becom- } \\
\text { ing more professional } \\
\text { and strategic. Scientists } \\
\text { engage only sparsely in } \\
\text { public science communi- } \\
\text { cation. There is a field of } \\
\text { "alternative" science com- } \\
\text { municators, such as NGOs } \\
\text { and think tanks, that have } \\
\text { hardly been addressed } \\
\text { from a science communi- } \\
\text { cation perspective }\end{array}$ & $\begin{array}{l}\text { Science is not a major } \\
\text { media topic; long-term } \\
\text { growth of science-related } \\
\text { coverage in legacy media; } \\
\text { media do not cover all sci- } \\
\text { entific fields equally; two } \\
\text { ideal-type modes of cov- } \\
\text { erage: popularization vs. } \\
\text { mediatization of science; } \\
\text { media coverage almost } \\
\text { always deviates from } \\
\text { science; evaluation of } \\
\text { science in media changes } \\
\text { over time }\end{array}$ & $\begin{array}{l}\text { Many people come in con- } \\
\text { tact with scientific infor- } \\
\text { mation mainly through } \\
\text { the media; scientific } \\
\text { communication may affect, } \\
\text { at an individual level, } \\
\text { science-relevant cognition, } \\
\text { emotions, and behaviour; } \\
\text { different psychological, } \\
\text { social, and cultural char- } \\
\text { acteristics of audience } \\
\text { members are linked to } \\
\text { the effects; the effects of } \\
\text { science communication } \\
\text { are strongly mediated by } \\
\text { their target group and their } \\
\text { object }\end{array}$ \\
\hline Gaps & $\begin{array}{l}\text { Scant research on organ- } \\
\text { izational science commu- } \\
\text { nicators and alternative } \\
\text { science communicators; } \\
\text { more international } \\
\text { comparison approaches } \\
\text { would be useful }\end{array}$ & $\begin{array}{l}\text { Most studies focus on } \\
\text { Western countries, print } \\
\text { media, STEM subjects; } \\
\text { more studies on online } \\
\text { presentations of science } \\
\text { are necessary }\end{array}$ & $\begin{array}{l}\text { Integration of national and } \\
\text { international longitudinal } \\
\text { surveys; effects on the } \\
\text { meso- and macro-levels of } \\
\text { society; theoretical devel- } \\
\text { opment with a focus on the } \\
\text { impact of science commu- } \\
\text { nication }\end{array}$ \\
\hline
\end{tabular}

\section{Analyses of the communicators of scientific communication}

Compared with other objects of science communication research, the communicators of science have been less in focus. The studies that do analyze the production side i. e., those actors who produce, select, and disseminate science-related content for the public - focus on different analytical levels, from the micro-level of individuals (such as journalists or scholars), to the meso-level of organizations (such as publishing houses, newsrooms, or universities), and to the societal macro-level (e.g. science journalism in general). In empirical studies, the micro- and meso-levels have received the most attention. Methodologically, analyses are based on responsive methods such 
as standardized surveys (Entradas and Bauer 2016; Post and Maier 2016), qualitative interviews (Guenther and Ruhrmann 2013; Poliakoff and Webb 2007), focus groups, and, partly, content analyses (Sumner et al. 2014) or rhetorical analyses (Fähnrich, Danyi, and Nothhaft 2015) and observational techniques (Felt and Fochler 2008; for an overview of methods, see Post 2017).

Early on, the respective research focused mainly on science journalists (cf. Dunwoody and Wormer in this volume). News media were seen as central in the "deficit model" approaches of science communication that were prevalent in the 1980s and 1990s, with journalists being the main translators of scientific knowledge for lay audiences (Bauer 2017; Bauer, Allum, and Miller 2007). Accordingly, scholars focused both on institutionalized science journalism, for example, on the organization and workings of media desks and newsrooms (Clark and Illman 2006), as well as on the role concepts, working routines, normative orientations, and backgrounds of individual journalists (e.g. Blöbaum 2008) (see Chapters 20 and 21, this volume).

Along with the paradigm shift toward more dialogical approaches, strategic science communication by universities and public relations (PR) departments (Marcinkowski et al. 2014; Entradas and Bauer 2016), museums and science centers (Schiele 2008), and individual scientists (Horst 2013) came into focus.

Recently, along with the emergence of a contextualized model of science communication (Akin and Scheufele 2017; cf. Schrögel and Humm in this volume), non-scientific science communicators, such as non-governmental organizations (NGOs), think tanks, political organizations, corporate communicators, etc., received more attention (cf. Fähnrich 2018; Yearley 2014) (see Chapter 23, this volume).

But while research on science communicators has evolved in recent years, systematic data is still missing on many aspects. Most studies analyze communicators in a small number of countries (e. g. UK: Hansen 1994; Bauer and Gregory 2007, Germany: Blöbaum 2008; Post and Maier 2016, US: Nisbet and Fahy 2015, Argentina: Kreimer, Levin, and Jensen 2011; Australia: Metcalfe and Gascoigne 1995; New Zealand: Ashwell 2014; Portugal: Entradas and Bauer 2016). Only a few country-comparative studies exist for science journalism (Bauer et al. 2013).

\subsection{Studies on science journalism}

Empirical studies show that science journalism and its output are "governed and shaped by both macro-level factors, such as ownership and cultural resonances, and by the more micro-level factors of journalistic practices, professional values, and organizational arrangements" (Hansen 1994: 111). Research shows an institutionalization of science journalism in many countries, leading to specific science desks and specialized science journalists working for print and broadcasting media or as freelancers from the 1970s and 1980s onwards (Dunwoody 2014; Gregory and Miller 1998). However, science journalism has not been as institutionalized as other fields of 
journalism. The US National Association of Science Writers, for example, has approximately 2,200 members (NASW 2011) and, thus, accounts for only a fraction of the approximately 122,000 US journalists (Weigold 2001). Blöbaum (2008) showed that only 1 percent of German journalists work in science journalism, with Kristiansen, Schäfer, and Lorencez (2016) reporting a proportion of 4.5 percent in Switzerland. With the rise of the Internet, science journalism and its working conditions have changed (Fahy and Nisbet 2011). As media organizations in many countries downsize due to eroding economic conditions, science writers "are often the first to go" (Bauer 2013: 5) and wind up working as freelancers or in science PR jobs.

Sociodemographically, science journalists have a specific profile: On average, they are older and hold higher academic degrees compared with other journalists. Moreover, a higher percentage of them - at least in Germany - are women (Blöbaum 2008).

Many science journalists' role conceptions seem to be rather traditional ones, but that may be changing; at least in continental Europe, they see themselves as gatekeepers aiming to “depict reality as it is” (Kristiansen, Schäfer, and Lorencez 2016: 136), to inform the audience about scientific facts, and to explain complex issues (Blöbaum 2008). In recent years and in certain situations, however, these role conceptions have diversified. An interview study (Stocking and Holstein 2009) showed that science journalists adopt different roles when approaching doubts about scientific findings. They work as "disseminators" who focus on "simply reporting"; "interpretive/investigative” journalists, who assess science information carefully; "populist mobilizers", who also refer to lay actors and their positions; or "adversarials", who take sides. In addition, Fahy and Nisbet (2011) showed that the roles of science journalists have also diversified with the rise of online and social media. On the Internet, science journalists function as curators, conveners, public intellectuals, and civic educators, among other roles.

Science journalists share some working routines with other journalists, but differ in some as well. Badenschier and Wormer (2011) have shown that science journalists' selection of topics is based on specific news factors, such as scientific relevance, actuality, intention, and astonishment, which differ from other fields of journalism. Furthermore, studies have shown that science journalists are more source-dependent than their colleagues, i.e., "[t]hey rely on a rather small number of influential scientific journals as primary sources, particularly 'Nature' and 'Science,' [...] and generally exhibit a rather strong source dependence” (Schäfer 2011: 406). Apart from their professional self-conceptions and specific working routines, journalists' understanding of science and their audience perceptions influence their work as well (ibid.). Focusing on journalists' knowledge of science-related issues, depending on their sources, Wilson (2000) showed that reporters working primarily on complex environmental issues and using scientists as core sources have the most accurate knowledge on climate change. Lehmkuhl and Peters (2016) analyzed how journalists deal with scientific uncertainty against the backdrop of their professional norms "to provide 
the most accurate representation possible because otherwise, journalism risks losing credibility" (Lehmkuhl and Peters 2016: 910). Based on the case study in the field of neuroscience, researchers found that journalists deal with uncertainty by omission, by contrasting conflicting messages, or by explicitly addressing the problem.

\subsection{Studies on strategic science communication}

Recent studies have focused on the "changing rationale of science communication" (Marcinkowski et al. 2014), demonstrating that science journalism becomes less important in building the public agenda on science, whereas strategic communication by science organizations is on the rise (e.g. Bauer and Gregory 2007). But so far, few studies have analyzed this interrelationship (for a summary of those, see Chapter 22 , this volume). An input-output study of scientific articles, university press releases, and news stories, for example, found that exaggeration in news stories is associated with exaggeration in press releases (Sumner et al. 2014).

Two types of studies focus on the strategic communication of science organizations: those focusing on structural aspects, i. e., the organization or rationale for the institutionalization of strategic science communication, and those looking more analytically at instruments or strategies of organizational science communication and their effectiveness.

Regarding the structural dimension, surveys indicate that strategic communication has become institutionalized and professionalized in science organizations in recent years (Peters et al. 2009; Marcinkowski et al. 2014). German universities, for example, have become "medialized" in this way because university boards increasingly demand public visibility for their universities (Kohring et al. 2013), which has become a core driver for the institutionalization and professionalization of organizational communication. Accordingly, media visibility is regarded as an objective in its own right (Peters et al. 2009). Entradas and Bauer (2016), looking at the Portuguese case, demonstrate that public visibility is also important for sub-units of universities such as institutes and chairs, who often develop strategic-communication functions themselves.

Many studies have focused on the instruments, channels, and techniques of organizational science communication, such as branding and marketing (Hemsley-Brown and Oplatka 2006), media relations (Serong et al. 2017), online communication (Metag and Schäfer 2017), and science events (Kawamoto, Nakayama, and Saijo 2011; Bultitude 2014). For instance, Serong et al. (2017) show that in the course of universities' media orientation, press releases are a core instrument, representing a "dominant link between academia and the media" (Sumner et al. 2014: 1). As a tool they have been rising in importance, although at different levels for different types of universities. Moreover, empirical studies show that online communication is growing in importance for organizational science communication and marketing. As Metag 
and Schäfer (2017) demonstrate, in German-speaking countries, science organizations hardly use the dialogical functions of social media, but rather stick to established informational communication strategies. In the framework of more engagement-oriented science communication, science events are on the rise, too (Fähnrich 2017).

In addition, the importance of individual scientists in science communication has risen (again). Historically, they were crucial for communicating science to the public until the early 20th century (Bauer 2011). With the rise of organizational communication at scientific institutions, and fostered by the development of online media, scientists have become even more visible as public communicators. In the public sphere, they either appear as representatives of their organizations (Horst 2013; Marcinkowski et al. 2014) or as individuals, often on social media such as blogs, Facebook, or Twitter (Brossard 2013; Wilkins 2008). Different studies show that most scientists think public engagement is important (Dudo and Besley 2016). However, results on attendance and motivation of researchers to take part in outreach activities such as public events differ. Whereas Peters et al. (2009) reported a rather high attendance rate for biomedical researchers, other studies claim that only a minority of scholars would actually engage in public science communication (Neresini and Bucchi 2010). Reasons for the lack in attendance are regarding it as pointless, no fun, or else they believe they lack the necessary skills (Poliakoff and Webb 2007), do not have the time, or fear damage to their careers (Riesch, Potter, and Davies 2013). Accordingly, there are few experts who are highly visible in the public sphere to impact the overall public perception of science (Davies 2008). They regard themselves as experts and mediators, but such visible scholars are particular scientists who do not necessarily represent entire scientific communities (Medvecky 2017). It is mostly senior scientists who are willing to talk to the media, to contribute to their organizations' media relations, and to represent science in the public sphere, but they are rather unwilling to "take part in activities aimed at the less-qualified 'lay public'” (Kreimer, Levin, and Jensen 2011: 45; cf. Bauer and Jensen 2011).

\subsection{Studies on other communicators}

Beyond actors from scientific communities, other actors are involved in science-related communication. There is a heterogeneous field of research on non-governmental organizations (NGOs) and think tanks (Yearley 2014), and their public communication in science-related fields, such as nuclear energy (Ho 2014; Aday and Livingston 2009) and climate change (Post and Maier 2016). Moreover, these actors are researched as “alternative-science communicators" (Maeseele 2009: 55) who, due to their strategic use of science, challenge notions of expertise, scientific certainty, and issue closure (Eden 2010). This is also the case for climate-change skeptical think tanks which at least in the US - impact policy and public discourse (Dunlap and Jacques 2013). Accordingly, such communicators are not only "alternative”, but also strategic science 
communicators who impede the public perception of science (Eden 2010; Post and Maier 2016).

\section{Analyses of science-related content}

Analyses of science-related media content make up a considerable portion of social-scientific analyses of science communication (see Chapter 20, this volume). A meta-analysis found more than 200 such studies published before 2010, as well as an increase in annually published articles over time (Schäfer 2012b; cf. Guenther and Joubert 2017: $8 \mathrm{f}$.).

Based on either quantitative or qualitative content analyses, or variants of discourse analysis, studies on science-related media content aim to extract information from textual, audio, and/or visual media data. Common analytical foci are the relative importance of different communicators in media content (e. g. Summ and Volpers 2016; Painter et al. 2016), the overall amount of scientific content found in media (e. g. Elmer, Badenschier, and Wormer 2008), media characterizations of science and its protagonists (Peters 1994; Schäfer 2009), the accuracy of the reporting as measured by scientific standards (e.g. Guenther et al. 2017), and the interpretative "framing” of science (Ruhrmann et al. 2015) and scientific findings (Kessler 2016).

Respective studies have scrutinized diverse objects. They exist in countries like the US (e.g. Pellechia 1997), UK (Cassidy 2005), and Germany (e.g. Metag and Marcinkowski 2014), tackling disciplines such as nanotechnology (e.g. Metag and Marcinkowski 2014), biotechnology (e.g. Holliman 2004), evolutionary psychology (Cassidy 2005), climate science (for an overview, see Schäfer 2015), and astronomy (e.g. Kiernan 2000) and appearing in media such as newspapers (Gavin 2009a), TV (Kessler 2016) or websites (Madden et al. 2012).

Notwithstanding the described diversity, several findings can be distilled from the field. First, the respective studies show that science is not, and has never been, a major media topic. Even though only a few studies have analyzed the extent to which science is represented in the media, they point in the same direction: Findings from the US, Australia, Germany, and Greece indicate that science-related content accounts for 1 percent to 3 percent of total media content (Dunwoody 2014).

Second, individual studies and meta-analyses (for an overview, see Bauer 2011) have shown long-term growth in science-related coverage in legacy media. After considerable fluctuations in the extent of science coverage in the late 19th and early 20th centuries (Bauer 2011), data indicate "a clear, almost linear increase of media stories about science and technology" (Schäfer 2017a: 58). Elmer, Badenschier, and Wormer (2008), for example, described an "unprecedented boom" in German legacy media coverage of science between 2003 and 2007. Similarly, Clark and Illman (2006) documented an increase in the New York Times' science-related coverage between 1980 
and 2000; Bucchi and Mazzolini (2003) found a rise in science journalism in Italy's leading newspaper over a 50-year timespan; Bauer et al. (2006) found a rising science journalism trend in UK and Bulgarian media; and Albaek, Christiansen, and Togeby (2003) documented how the representation of "scientific experts" has increased in Danish newspapers over the past 40 years. But this trend seems to have halted in the early 2000s. Until 2006, the share of science content in mass media seemingly stagnated when compared with other news content (Bauer 2011).

A third finding is that the media are not covering all scientific fields equally. When studies analyze the designated "science" sections of mass media, they find a strong focus on the natural sciences. Elmer, Badenschier, and Wormer (2008), for example, found hardly any social sciences or humanities in the science sections, which are dominated by medical research, environmental sciences, and biology (cf. Nelkin 1995). Beyond the "science" sections, however, a more pluralistic set of disciplines appears. Albaek, Christiansen, and Togeby (2003), for example, show that most scientific experts appearing in general media are social scientists, and that their representation increased considerably between 1961 and 2001. STEM scientists appear less often, and their share among experts has decreased over time. The proportion of scholars from the humanities has remained constant over time at roughly 10 percent. Similarly, Summ and Volpers (2016) found that social sciences and STEM subjects account for the largest shares of the media's science coverage, with humanities making up 17 percent of 1,730 analyzed newspaper articles.

Apart from the degree of media coverage on science-related disciplines, research has focused extensively on how science was portrayed. Generally, and as a fourth result, scholars have described two ideal-type modes of media coverage of science. On one hand, they have shown that it often corresponds to a "popularization" (cf. Peters 1994: 169; Meier and Feldmeier 2005: 203) or "science du chef” (Bucchi 1998) mode. This type of coverage is often found in science sections (Evans and Hornig Priest 1995) and mirrors the communication within the scientific community in several respects, except that it is carried over to a lay register while trying to stick to the scientific content. Coverage is typically triggered by scientific events or publications, relies heavily on scientific sources, and views science inherently positively. On the other hand, studies have described a "contextualized" (Brossard and Scheufele 2013) or "mediatization" (Schäfer 2009) mode of coverage in which general criteria for journalistic reporting and the media apply to science coverage. These articles often appear outside the science sections and are triggered by socio-political or socio-cultural events. This coverage relies less on scientific sources, is considerably more conflictual, and often confronts scientists with politicians, NGO representatives, citizens, etc. (Peters 1994; Schäfer 2009). Such reporting has been used to cover controversial issues such as animal (Weingart, Salzmann, and Wörmann 2006) or human cloning, (Holliman 2004) and stem-cell research (Nisbet, Brossard, and Kroepsch 2003).

Overall, the foci of content analyses of science-related media content have shifted over time. Early on, studies often tried to assess the accuracy of media coverage, either 
by comparing it with scientific publications (e.g. Sumner et al. 2014), or by asking scientists to evaluate its accuracy (Haller 1996). These efforts have shown, for the fifth result, that media coverage almost always deviates to some extent from scientific descriptions. Ankney, Heilman, and Kolff (1996), for example, found more than 200 errors in 42 newspaper articles on medical research. Furthermore, media reporting has been described as exaggerated and sensationalist (e.g. Knudsen 2005), simplified, and devoid of complex issues (Brechman, Lee, and Cappella 2009), or as stereotyping scientists by portraying them as magicians or heroes (LaFollette 1990). In addition, media have been shown to be struggling with the uncertainties that often accompany scientific information. These qualifiers are either not represented - "News reports of scientific research are rarely hedged [and] do not contain caveats, limitations, or other indicators of scientific uncertainty" (Jensen 2008: 347) - or are transformed into news themselves by interpreting them as controversies within the scientific community (Rödder and Schäfer 2010).

With this shift from a "public understanding" model of science communication toward more constructivist models that understand media not merely as translators of science, but as active producers of content, the analytical focus of content analyses also has changed. Many scholars have analyzed how science is "framed" in media reporting, i.e., the interpretive devices used to embed and make sense of scientific issues. Framing research has shown that different facets of science can be selected and made salient in media coverage. Genetically modified organisms, for example, can be framed as antidotes to world hunger or as manipulations of God's creation (e.g. Durant, Bauer, and Gaskell 1998), and climate change can be interpreted as a threat to mankind or as a scientific theory that is not yet fully proven (for an overview, see Schäfer and O'Neill 2017). Even the same scientific finding can be framed in varying ways throughout the media (Kessler 2016; Ruhrmann et al. 2015). Studies have shown that the framing of many scientific issues is context-sensitive and differs among various media (e.g. Boykoff 2008; Carvalho 2007) and for different countries (e.g. Boykoff and Boykoff 2007). Still, cross-national framing analysis across longer time-spans has tried to develop generic frame sets that work across topics, distinguishing frames such as "progress”, "Pandora’s Box”, or “ethical implications” (e.g. Durant, Bauer, and Gaskell 1998).

Partly connected to the framing perspective, studies also have focused on the evaluation of science in media coverage and have shown that it has changed over time. They have described a more affirmative bias in coverage early on, in which science was covered mostly affirmatively (Nelkin 1995), with a more critical science journalism developing in the 1970s and growing stronger until the 1990s and early 2000s (Bauer et al. 2006; Elmer, Badenschier, and Wormer 2008). This was accompanied by media coverage on issues such as stem-cell research, green biotechnology, climate science, and gene editing becoming more pluralistic and partly contested, with large swaths of coverage appearing outside of science sections, featuring mostly non-scientists as sources discussing ethical, legal, and social frames 
in ambivalent or even critical tones (Schäfer 2009). More recent analysis, however, hints at a less-critical science journalism emerging again due to a combination of science journalists' working conditions worsening in many countries (for overviews, see Dunwoody 2014; Schäfer 2017a) and the corresponding growth in science communication from different societal stakeholders and science PR representatives (or agencies, experts, or groups). Several scholars have diagnosed a development "from a logic of journalism [...] towards a source-driven reportage of science" (Bauer and Gregory 2007: 33) in recent years. When communicators outside science are proliferating more information about science, "time-pressed reporters [are again] increasingly reliant on information subsidies from scientific institutions, universities, and public relations agencies to find material" (Fahy and Nisbet 2011: 784), a development that may move science coverage (again) toward a more-affirmative, less-critical style (Bauer et al. 2013: 27).

Analyses of science-related legacy media content - which is also partly presented online - increasingly have been supplemented by studies of online and social media communication recently (cf. Brossard and Scheufele 2013). Even though the extent of science-related content online is difficult to assess, research has shown that a large amount of such content is available online (e. g. Schäfer 2012a: 532).

Many studies have focused on the accuracy of online representations of science, often driven by the assumption that the lack of quality control and journalistic gatekeeping online might result in substandard portrayals of scientific issues. They have shown that online, highly detailed and exact presentations of science can be found, as well as "extreme and unorthodox viewpoints" (Ladle, Jepson, and Whittaker 2005: 235; cf. Bubela et al. 2009; Cacciatore et al. 2012). Revolving around issues such as climate science, vaccinations, or evolution theory, and particularly in Anglophone countries, accurate portrayals of science are accompanied by massive criticism and rhetoric anti-science (e. g. Barr 2011; Gavin 2009b). Connected to this, studies have also shown that deliberative quality in online discourse on these issues often seems to be lacking. While "a much wider set of individuals and organizations" (Carvalho 2007: 1) can participate in comments sections, Facebook or Twitter timelines, online forums, etc., this does not improve the quality of the debate, as measured by normative standards of public-sphere theory. Communication is often "limited and unstructured" (Zavestoski, Shulman, and Schlosberg 2006: 386), "polarized and sometimes ideologically driven" (Holliman 2004: 834), and can "descend to playground level” (Gavin 2009b: 469). 


\section{Analyses of the uses and effects of science communication}

A large body of studies on science communication focuses on the audience. It analyzes what information people use regarding scientific topics, which media they use to acquire this information, how they use it, and how this usage affects both individuals and public opinion.

Historically, studies adhering to the deficit model of science communication have focused on effects on people's knowledge about science or on effects on people's attitudes toward science. Studies subscribing to the public engagement with science paradigm, however, did not employ a deficit heuristic and analyzed a broader range of communication effects on science-related attitudes, interests, beliefs, and trust (Metag 2017; Nisbet and Scheufele 2009).

In recent years, several shifts have been identified in the respective research. Nisbet and Markowitz (2016) identified a change from theoretical and descriptive studies on public opinion formation to a more applied and practical focus, accompanied by an increased focus on developing and testing specific communication methods and approaches, and on strategically defined goals, such as gaining public attention and generating concern about a problem, responding to or correcting false information, or mobilizing members of the public to become involved. In this process, studies have adopted disciplinary theories from communication science, psychology, pedagogy, or sociology to analyze the use and impact of science communication (Metag 2017; Trench and Bucchi 2010). A second shift is visible in the goals of science communication and respective research. Many scholars have moved from focusing on the awareness and understanding of audiences to their engagement with and participation in science (Bucchi and Trench 2014). Finally, a third change is visible in the media that were analyzed, with studies moving away from legacy news media toward science communication online (Brossard 2013) (see Chapters 28 and 31, this volume).

\subsection{How individuals use science communication}

Many studies have analyzed where individuals inform themselves about science, what sources they choose, how they perceive these sources and their content, and how this information is processed (Akin and Landrum 2017; Nisbet et al. 2002). Such questions are regularly asked in surveys in the US (e.g. National Science Board 2016), Europe (e. g. European Commission 2013), and elsewhere, and they are the focus of numerous other studies.

They show that many people come in contact with science mainly through traditional mass media (BBVA Foundation 2011). TV and traditional newspapers, in this regard, appear to remain the most common sources in many countries (European 
Commission 2013). But the role of online sources is increasing. For nearly half of Americans, the Internet was their primary source of science information in 2014, compared with only about a tenth of Americans in 2001 (National Science Board 2016). People also come in contact with scientific information through diverse informal science and cultural institutions (National Science Board 2016; Falk and Needham 2013).

Representative surveys show that citizens' interest in science and scientific issues is medium to high in the US and Europe (see Besley 2013 for an overview). Over half of respondents said they are interested in scientific developments (BBVA Foundation 2011; European Commission 2013; National Science Board 2016; Schäfer et al. 2018). However, a third of Americans (like in many other OECD countries) said that it is not important to know about science in their daily lives (National Science Board 2016). The wider European population particularly has little to do with science and feels it is not that well-informed about scientific issues (BBVA Foundation 2011; European Commission 2013). Swiss people, for example, deal with scientific topics mainly out of pure curiosity, to gain knowledge, to better understand scientific topics, to have a say, and to get information from others (Schäfer et al. 2018).

Regarding sociodemographics, it becomes apparent that people with higher education levels in particular are more interested in science (European Commission 2013) and more involved in science-related activities, such as visits to science and technology museums (BBVA Foundation 2011). Focusing on Internet searches for scientific information, gender, age, and education are clear determinants of activity frequency (BBVA Foundation 2011). Public interest differed among specific issues. Most people are very interested in new medical discoveries, health issues, and environmental research, and are only moderately interested in space exploration or political issues (BBVA Foundation 2011; National Science Board 2016). Attentiveness to specific science issues varied significantly between and within countries (BBVA Foundation 2011).

At the same time, studies from different countries have shown that populations can be segmented into people with different attitudes toward science who also differ in their information and media-use patterns. Such segmentations were detected repeatedly for issues such as climate change (for an overview, see Hine et al. 2014) and health (Maibach et al. 2006), and sometimes for science in general (Kawamoto, Nakayama, and Saijo 2011; OST and Wellcome Trust 2000; Research Councils UK 2008; Schäfer et al. 2018). Studies found that the segment with different science-related attitudes can be reconstructed, and that, for example, the "technophiles" identified in the British study use quality media extensively to get information about science, while the "not for me" segment mainly consumes entertainment shows on TV and rarely encounters scientific content (OST and Wellcome Trust 2000). Science communication is more likely to reach those who are already highly interested in science (Bubela et al. 2009; Fähnrich 2017). 


\subsection{Effects of public science communication on individuals}

Numerous studies have tried to assess the effects of public science communication on non-scientists. A wide variety of phenomena can be understood as effects, such as cultivation of ideas about science through media, setting of topic importance for the public (agenda setting), mediating of interpretation patterns (framing effects), increase in knowledge (gaps), or persuasion (Metag 2017). Therefore, studies have focused on different potential dimensions in which such effects may manifest themselves, such as people's awareness of certain scientific issues; their knowledge about science, i. e., their scientific literacy; and their attitudes toward science, including trust toward science and their behaviour regarding scientific knowledge and issues (see Chapter 2, this volume). The effects of science communication differ strongly - apart from individual, sociocultural, and other factors - depending on these dimensions.

In accordance with the background of deficit model and scientific literacy, studies have hypothesized that providing scientific information to a broader audience will reverse negative attitudes and perhaps even help foster favored social or political action. Several surveys indicate that knowledge and attitudes about science research partially depend on the availability of science-related news (European Commission 2013; National Science Board 2016); or precisely, those who are interested in it and feel informed are much more likely to have a positive view of science (European Commission 2013). Factors such as formal education, involvement in informal education (e.g. visiting museums or watching science TV programs), and media usage play a central role in how people think about science (National Science Board 2016). But many studies demonstrate that gaining knowledge does not necessarily change attitudes about scientific issues because they are complex and tend to be issue-specific, depending on personal involvement, and are driven by personal predispositions (Akin and Scheufele 2017; Varner 2014). Higher levels of public knowledge will not necessarily increase public support for and interest in science; the public's attitudes about science are entangled in individuals' social and political environments, which are shaped by mass media portrayals and confounded by interpersonal and cultural influences (e.g. Akin and Scheufele 2017; Hallman 2017; Kahan et al. 2012; Pennycook and Rand 2017).

In addition, studies have shown that for the audience, it is sometimes difficult to deal with scientific information to make personal, professional, and civic decisions because of a limited understanding of how scientific knowledge and epistemological processes work and because of their influence on individual cognitive, affective, and behavioural psychological processes (Bromme and Goldman 2014; Kahan et al. 2012; Pennycook and Rand 2017). The audience's trust in science is important for each citizen, even for completely modern societies, and is mediated by and also mediates science communication (Akin and Scheufele 2017; Bromme and Goldman 2014; Fischhoff and Scheufele 2013).

Most studies on the impact and reception of scientific communication investigate the effects at an individual level and show the impact on science-relevant cognitions 
such as epistemological beliefs (Guenther and Kessler 2017) or issue-specific beliefs (Kessler 2016), emotions such as risk perception (Slovic 2010), behaviours such as willingness to vaccinate (Donahue et al. 2018), or information seeking (Kessler and Guenther 2017; Kessler and Zillich 2018). Many findings on the impact of science communication are generated in special research fields, such as health communication or risk communication, and standardized experiments usually are carried out as part of analyses (Metag 2017).

Media coverage often sets the public agenda and, as mentioned above, the science communication process is also a process of framing, which frames the debate in relation to scientific issues. Audiences pay more attention to certain aspects of an issue or of a science debate depending on how an issue is framed in scientific communication (Bubela et al. 2009; Kessler 2016). However, research indicates that different media have different effects on attitudes toward science (e. g. Dudo et al. 2010). Empirically linked to the effects of science communication processes are different psychological, social, and cultural characteristics of audience members, such as personal values, issue proximity, and familiarity, which shape mental models, schemes, and beliefs about particular issues, furthering their interpretations of scientific communication (Akin and Scheufele 2017; Fischhoff and Scheufele 2013; Kessler 2016).

Research has also shown that the effects of science communication are strongly mediated by their target group and their object. Populations can be divided into many public segments, each with its own understanding of science via previous knowledge, beliefs, attitudes, trusts, etc. (Bubela et al. 2009; Bucchi and Trench 2014; Nisbet and Scheufele 2009; Scheufele, Jamieson, and Kahan 2017). Because these segments inform themselves differently about science and science communication, the effects of science communication may differ among them (Metag and Schäfer 2018; Schäfer et al. 2018). In addition, the effects of science communication also vary depending on the scientific issue discussed (Schäfer 2014). The media's reporting on scientific issues not only influences public perceptions, but also shapes policy and even science debate (Bubela et al. 2009).

\section{Biases, desiderata, and research perspectives}

Analyses of science communication from the social and communication sciences have matured as a field of academic inquiry (Rauchfleisch and Schäfer 2018) and produced robust findings on science communicators, the diversifying media ecosystem, and its audiences (Bubela et al. 2009). At the same time, some aspects of science communication have been systematically under-researched, and several gaps and biases require scholarly attention in the future.

Several of these gaps are specific to the described subfields of the science of science communication: 
- Among analyses of science communicators, science journalists and, more recently, PR experts and individual scientists have received much attention. In turn, organizational communication from universities or research centers, which are becoming more important, have not received much scholarly scrutiny (Entradas and Bauer 2016; Fähnrich et al. 2019). The same can be said for "new" actors in science communication, such as think tanks, NGOs, and corporations that have just emerged in the realm of science communication research, along with the appearance of the "context" model of science communication (Akin and Scheufele 2017). Moreover, interactions among different science communicators have rarely been examined. In addition, international and comparative studies could enrich the understanding of science communicators in an age when public-agenda building and the perception of science extend beyond national boundaries.

- While media representations of science have received much scholarly attention, this subfield also shows gaps and biases. More studies should focus on non-Western countries, non-print media, and disciplines beyond STEM subjects. Some of these research shifts are occurring (such as a rise in studies on Asian countries or online media; see Schäfer 2012b), but others seem to be persistent (such as the focus on STEM disciplines). This seems particularly necessary as existing content analyses have shown that media coverage differs strongly from one context to another. Content analyses of online communication about science exhibit additional gaps. The specifics of online presentations of science merit more attention, such as novel contextual cues like social recommendations, commentary, "likes", or "shares" that accompany almost all online content and that have been shown to influence interpretation as well (e.g. Anderson et al. 2014; for an overview see Hanauska and Leßmöllmann 2018).

- Research focusing on the uses and effects of science communication, including its recent productivity, also exhibits desiderata. Future research should focus on effects on the meso- and macro-levels of society (Akin and Scheufele 2017), as well as take into account feedback effects on science, its protagonists, and institutions (e. g. using the mediatization of science frameworks; see Schäfer 2014). In addition, making use of the increasing availability of complex data should provide researchers with new opportunities. An integration of national and international longitudinal surveys and complementary data streams of media content could allow scholars to develop dynamic models of science communication (Bauer and Falade 2014). A great challenge remains in reaching audiences who lack an interest in science and ignore scientific content on the web; this is a risk concerning the public's degree of engagement with science policy debates (Bubela et al. 2009). Apart from any effects from science communication on audiences outside of scientific communities, effects are also possible on scientific communities and science themselves - both at the micro-level of individual scientists (Ivanova et al. 2013), the meso-level of scientific institutions such as universities (Kohring et al. 
2013; Marcinkowski et al. 2014), and at the macro-level of science as such (Peters et al. 2009).

- In addition to these gaps within the three subfields, a stronger connection between these three subfields is needed. Coupling analyses of communicators' positions, aims, and strategies with analyses of their public or online representation would be illuminating, as would the combination of analyses of media and online content with studies of their use and effects.

In addition, the research field would certainly profit from more theoretical work. Further theoretical development, with a focus on the impact of science communication, especially on a macro-level, is needed to give researchers, students, and professional practitioners better tools to describe, classify, and explain what they observe to understand relations and processes, and to assess effects and outcomes (Metag 2017; Trench and Bucchi 2010). Scholars should use empirical methods and studies to consequently develop and validate models of science communication, further differentiate and characterize the public's desire for science, and evaluate methods for effective science communication (see also van der Sanden, Maarten, and Trench 2010). The social transformation and changes in media technology have created new public spaces for science communication, and they demand more complex and dynamic theoretical models to properly grasp the mutual exchanges between science and public audiences (Bauer and Falade 2014; Bucchi and Trench 2014). Theoretical development in the field could be assisted by further imports of theories and approaches from various disciplines with which it is associated.

Related to this is the need for continued reflection on the nexus of the science of science communication and science communication itself, i. e., on the practical importance of research on science communication. It should be discussed how science can best be communicated within ever-shifting social, scientific, and political landscapes; how the public can best be involved; how the increasingly diverse media landscape, especially the Internet, incorporates selective exposure of scientific communication; and what the consequences of those processes are. What makes scientific communication effective, how can the interest and understanding of audiences be increased, and how should science communication adjust to audience characteristics - empirical questions for future research on science communication (Akin and Landrum 2017; Scheufele, Jamieson, and Kahan 2017; see also Chapter 31, this volume). A principal future challenge is the production of comprehensive research that includes a diversity of media platforms and audiences, and facilitates conversations with the public that recognize, respect, and incorporate differences in knowledge, values, perspectives, and goals (Nisbet and Scheufele 2009). Such research would be crucially important for enabling policy debates and decisions based on the best available scientific evidence. 


\section{References}

Aday, Sean \& Steven Livingston. 2009. NGOs as intelligence agencies: The empowerment of transnational advocacy networks and the media by commercial remote sensing in the case of the Iranian nuclear program. Geoforum 40(4). 514-522.

Akin, Heather \& Ashley R. Landrum. 2017. A recap: Heuristics, biases, values, and other challenges to communicating science. In Kathleen H. Jamieson, Dan M. Kahan \& Dietram Scheufele (eds.), The Oxford handbook on the science of science communication, 455-460. 0xford: Oxford University Press.

Akin, Heather \& Dietram A. Scheufele. 2017. Overview of the science of science communication. In Kathleen H. Jamieson, Dan M. Kahan \& Dietram Scheufele (eds.), The Oxford handbook on the science of science communication, 25-33. Oxford: Oxford University Press.

Albæk, Erick, Peter M. Christiansen \& Lise Togeby. 2003. Experts in the mass media: Researchers as sources in Danish daily newspapers, 1961-2001. Journalism \& Mass Communication Quarterly 80(4). 937-948.

Anderson, Ashley A., Dominique Brossard, Dietram A. Scheufele, Michael A. Xenos \& Peter Ladwig. 2014. The "nasty effect:" online incivility and risk perceptions of emerging technologies. Journal of Computer-Mediated Communication 19(3). 373-387.

Ankney, Raymond N., Patricia Heilman \& Jacob Kolff. 1996. Newspaper Coverage of the Coronary Artery Bypass Grafting Report. Science Communication 18(2). 153-164.

Ashwell, Douglas J. 2014. The challenges of science journalism: The perspectives of scientists, science communication advisors and journalists from New Zealand. Public Understanding of Science 25(3). 379-393.

Badenschier, Franziska \& Holger Wormer. 2011. Issue selection in science journalism: Towards a special theory of news values for science news? In Simone Rödder, Martina Franzen \& Peter Weingart (eds.), The sciences' media connection - Communication to the public and its repercussions. Sociology of the Sciences Yearbook. Dordrecht: Springer.

Barr, Stewart. 2011. Climate forums: virtual discourses on climate change and the sustainable lifestyle. Area 43(1). 14-22.

Bauer, Martin W. 2011. Public attention to science 1820-2010. A 'longue durée' picture. In Simone Rödder, Martina Franzen \& Peter Weingart (eds.), The sciences' media connection Communication to the public and its repercussions. Sociology of the Sciences Yearbook, 35-58. Dordrecht: Springer.

Bauer, Martin W. 2013. The knowledge society favours science communication, but puts science journalism into the clinch. In Patrick Baranger \& Bernard Schiele (eds.), Science communication today. International perspectives, issues and strategies. Paris: CNRS Editions.

Bauer, Martin W. 2017. Kritische Beobachtungen zur Geschichte der Wissenschaftskommunikation [Critical observations on the history of science communication]. In Heinz Bonfadelli, Birte Fähnrich, Corinna Lüthje, Jutta Milde, Markus Rhomberg \& Mike S. Schäfer (eds.), Forschungsfeld Wissenschaftskommunikation, 17-40. Wiesbaden: Springer VS.

Bauer, Martin W., Kristina Petkova, Pepka Boyadjieva \& Galin Gornev. 2006. Long-term trends in the public representation of science across the 'Iron Curtain': 1946-1995. Social Studies of Science 36(1). 99-131.

Bauer, Martin W. \& Jane Gregory. 2007. From journalism to corporate communication in post-war Britain. In Martin W. Bauer \& Massimiano Bucchi (eds.), Science, journalism and society: Science communication between news and public relations, 33-52. London: Routledge.

Bauer, Martin W., Nick Allum \& Steve Miller. 2007. What can we learn from 25 years of PUS survey research? Liberating and expanding the agenda. Public Understanding of Science 16(1). 79-95. 
Bauer, Martin W. \& Pablo Jensen. 2011. The mobilization of scientists for public engagement. Public Understanding of Science 20(1). 3-11.

Bauer, Martin W., Susan Howard, Yulye J. R. Ramos, Luisa Massarani \& Luis Amorim. 2013. Global science journalism report: Working conditions \& practices, professional ethos and future expectations: Report. London: Science and Development Network.

Bauer, Martin W. \& Bankole A. Falade. 2014. Public understanding of science: Survey research around the world. In Massimiano Bucchi \& Brian Trench (eds.), Handbook of public communication of science and technology, 2nd edn., 140-159. London: Routledge.

BBVA Foundation. 2011. International study on scientific culture: Understanding of science. Bilbao: BBVA.

Besley, John C. 2013. The state of public opinion research on attitudes and understanding of science and technology. Bulletin of Science, Technology \& Society.

Blöbaum, Bernd. 2008. Wissenschaftsjournalisten in Deutschland. Profil, Tätigkeiten und Rollenverständnis [Science journalists in Germany. Profile, activities and role understanding]. In Holger Hettwer, Markus Lehmkuhl, Holger Wormer \& Franco Zotta (eds.), WissensWelten. Wissenschaftsjournalismus in Theorie und Praxis, 245-260. Gütersloh: Bertelsmann Stiftung.

Boykoff, Maxwell T. 2008. Media and scientific communication: a case of climate change. In D. G. E. Liverman, C. P. G. Pereira, \& B. Marker (eds.), Communicating environmental geoscience (Geological Society Special Publication), 11-18.

Boykoff, Maxwell T. \& Jules M. Boykoff. 2007. Climate change and journalistic norms: A case-study of US mass-media coverage. Geoforum 38(6). 1190-1204.

Brechman, Jean, Chul-joo Lee \& Joseph N. Cappella. 2009. Lost in translation?: A comparison of cancer-genetics reporting in the press release and its subsequent coverage in the press. Science Communication 30(4). 453-474.

Bromme, Rainer \& Susan R. Goldman. 2014. The public's bounded understanding of science. Educational Psychologist 49(2). 59-69.

Brossard, Dominique. 2013. New media landscapes and the science information consumer. Proceedings of the National Academy of Sciences.

Brossard, Dominique \& Dietram A. Scheufele. 2013. Science, new media, and the public. Science 339(40). 40-41.

Bubela, Tania, Matthew C. Nisbet, Rick Borchelt, Fern Brunger, Cristine Critchley, Edna Einsiedel, Gail Geller, Anil Gupta, Jurgen Hampel, Robyn Hyde-Lay, Eric W. Jandciu, S. A. Jones, Pam Kolopack, Summer Lane, Tim Lougheed, Brigitte Nerlich, Ubaka Ogbogu, Kathleen O’Riordan, Colin Ouellette, Mike Spear, Stephen Strauss, Thushaanthini Thavaratnam, Lisa Willemse \& Timothy Caulfield. 2009. Science communication reconsidered. Nature Biotechnology 27(6). 514-518.

Bucchi, Massimiano. 1998. Science and the media. Alternative routes in scientific communication (Routledge Studies in Science, Technology and Society). London \& New York: Routledge.

Bucchi, Massimiano \& Renato G. Mazzolini. 2003. Big science, little news: science coverage in the Italian daily press, 1946-1997. Public Understanding of Science 12(1). 7-24.

Bucchi, Massimiano \& Brian Trench. 2014. Science communication research: Themes and challenges. In Massimiano Bucchi \& Brian Trench (eds.), Routledge handbook of public communication of science and technology, 2nd edn., 1-14. London: Routledge.

Bultitude, Karen. 2014. Science festivals: do they succeed in reaching beyond the 'already engaged'? Journal of Science Communication 13(4). C01.

Cacciatore, Michael A., Ashley A. Anderson, Doo-Hun Choi, Dominique Brossard, Dietram A. Scheufele, Xuan Liang, Peter J. Ladwig, Michael Xenos \& Anthony Dudo. 2012. Coverage of emerging technologies: A comparison between print and online media. New Media \& Society 14(6). 1039-1059. 
Carvalho, Anabela. 2007. Ideological cultures and media discourses on scientific knowledge: re-reading news on climate change. Public Understanding of Science 16(2). 223-243.

Cassidy, Angela. 2005. Popular evolutionary psychology in the UK: an unusual case of science in the media? Public Understanding of Science 14(2). 115-141.

Clark, Fiona \& Deborah L. Illman. 2006. A longitudinal study of the New York Times Science Times section. Science Communication 27(4). 496-513.

Davies, Sarah R. 2008. Constructing communication. Science Communication 29(4). 413-434.

Donahue, Kelly, Kristin Hendrix, Lynne Sturm \& Gregory Zimet. 2018. Provider communication and mothers' willingness to vaccinate against human papillomavirus and influenza: A Randomized Health Messaging Trial. Academic Pediatrics 18(2). 145-153.

Dudo, Anthony, Dominique Brossard, James Shanahan, Dietram A. Scheufele, Michael Morgan \& Nancy Signorielli. 2010. Science on television in the 21st century: Recent trends in portrayals and their contributions to public attitudes toward science. Communication Research 38(6). 754-777.

Dudo, Anthony \& John C. Besley. 2016. Scientists' prioritization of communication objectives for public engagement. PLoS One 11(2). e0148867.

Dunlap, Riley E. \& Peter J. Jacques. 2013. Climate change denial books and conservative think tanks: Exploring the connection. The American Behavioral Scientist 57(6). 699-731.

Dunwoody, Sharon. 2014. Science journalism. In Massimiano Bucchi \& Brian Trench (eds.), Routledge handbook of public communication of science and technology, 2nd edn., 15-26. London: Routledge.

Durant, John, Martin W. Bauer \& George Gaskell (eds.). 1998. Biotechnology in the public sphere. A European sourcebook. London: Science Museum.

Eden, Sally. 2010. NGOs, the science-lay dichotomy, and hybrid spaces of environmental knowledge. In Peter Meusburger, David Livingstone \& Heike Jöns (eds.), Geographies of Science, 217-230. Dordrecht: Springer Netherlands.

Elmer, Christina, Franziska Badenschier \& Holger Wormer. 2008. Science for everybody? How the coverage of research issues in German newspapers has increased dramatically. Journalism \& Mass Communication Quarterly 85(4). 878-893.

Entradas, Marta \& Martin M. Bauer. 2016. Mobilisation for public engagement: Benchmarking the practices of research institutes. Public Understanding of Science 26(7). 771-788.

European Commission. 2013. Special Eurobarometer 401: Responsible Research and Innovation (RRI), Science and Technology. Responsible Research and Innovation (RRI), Science and Technology.

Evans, William \& Susanna Hornig Priest. 1995. Science content and social context. Public Understanding of Science 4(4). 327-340.

Fähnrich, Birte. 2017. Wissenschaftsevents zwischen Popularisierung, Engagement und Partizipation [Science events between popularization, engagement and participation]. In Heinz Bonfadelli, Birte Fähnrich, Corinna Lüthje, Jutta Milde, Markus Rhomberg \& Mike S. Schäfer (eds.), Forschungsfeld Wissenschaftskommunikation, 165-182. Wiesbaden: Springer VS.

Fähnrich, Birte. 2018. Digging deeper? Muddling through? How environmental activists make sense and use of science. Journal of Science Communication.

Fähnrich, Birte, Claudia J. Danyi \& Howard Nothhaft. 2015. The German plagiarism crisis: Defending and explaining the workings of scholarship on the front stage. Journal of Science Communication 19(1). 20-38.

Fähnrich, Birte, Julia Metag, Senja Post \& Mike S. Schäfer. 2019. Hochschulkommunikation aus kommunikationswissenschaftlicher Perspektive - Einleitung [University communication from a communication science perspective - Introduction]. In Birte Fähnrich, Julia Metag, Senja Post \& Mike S. Schäfer (eds.). Forschungsfeld Hochschulkommunikation [The Field of University Communication], 1-21. Wiesbaden: Springer VS. 
Fahy, Declan \& Matthew C. Nisbet. 2011. The science journalist online: Shifting roles and emerging practices. Journalism 12(7). 778-793.

Falk, John H. \& Mark D. Needham. 2013. Factors contributing to adult knowledge of science and technology. Journal of Research in Science Teaching 50(4). 431-452.

Felt, Ulrike \& Maximilian Fochler. 2008. The bottom-up meanings of the concept of public participation in science and technology. Science and Public Policy 35(7). 489-499.

Fischhoff, Baruch \& Dietram A. Scheufele. 2013. The science of science communication. Proceedings of the National Academy of Sciences 110(Supplement 3). 14031-14032.

Gascoigne, Toss, Donghong Cheng, Michel Claessens, Jenni Metcalfe, Bernard Schiele \& Shunke Shi. 2010. Is science communication its own field. Journal of Science Communication 9(3). C04.

Gavin, Neil T. 2009a. Addressing climate change: a media perspective. Environmental Politics 18(5). 765-780.

Gavin, Neil T. 2009b. The web and climate change politics Lessons from Britain? In T. Boyce \& J. Lewis (eds.), Climate change and the media, 129-142. New York: Peter Lang.

Gregory, Jane \& Steve Miller. 1998. Science in public. Communication, culture, and credibility. New York: Plenum.

Guenther, Lars, Jenny Bischoff, Anna Löwe, Hanna Marzinkowski \& Marcus Voigt. 2017. Scientific evidence and science journalism. Journalism Studies. 1-20.

Guenther, Lars \& Marina Joubert. 2017. Science communication as a field of research: Identifying trends, challenges and gaps by analysing research papers. Journal of Science Communication 16(2). 1-19.

Guenther, Lars \& Sabrina H. Kessler. 2017. Epistemological dimensions on screen: The role of television presentations in changing conceptions about the nature of knowledge and knowing. Communications: The European Journal of Communication Research 42(4). 481-501.

Guenther, Lars \& Georg Ruhrmann. 2013. Science journalists' selection criteria and depiction of nanotechnology in German media. Journal of Science Communication 12(3). 1-17.

Haller, Michael. 1996. Defizite im Wissenschaftsjournalismus [Deficits in science journalism]. In Winfried Göpfert \& Stephan Ruß-Mohl (eds.), Wissenschaftsjournalismus. Ein Handbuch für Ausbildung und Praxis (List Journalistische Praxis), 13-21. München \& Leipzig: Paul List.

Hallman, William K. 2017. What the public thinks and knows about science - and why it matters. In Kathleen H. Jamieson, Dan M. Kahan \& Dietram Scheufele (eds.), The Oxford handbook on the science of science communication, 61-72. Oxford: Oxford University Press.

Hanauska, Monika \& Annette Leßmöllmann. 2018. Dialogizität im Wissenschaftsjournalismus [Dialogicity in science journalism]. In Nina Janich \& Karin Birkner (eds.), Handbuch Text und Gespräch, 371-396. Berlin \& Boston: de Gruyter.

Hansen, Anders. 1994. Journalistic practices and science reporting in the British press. Public Understanding of Science 3(2). 111-134.

Hemsley, Brown, Jane \& Izhar Oplatka. 2006. Universities in a competitive global marketplace: A systematic review of the literature on higher education marketing. International Journal of Public Sector Management 19(4). 316-338.

Hine, Donald W., Joseph P. Reser, Mark Morrison, Wendy J. Phillips, Patrick Nunn \& Ray Cooksey. 2014. Audience segmentation and climate change communication: conceptual and methodological considerations. Wiley Interdisciplinary Reviews: Climate Change 5(4). 441-459.

Ho, Ming-sho. 2014. The Fukushima effect: explaining the resurgence of the anti-nuclear movement in Taiwan. Environmental Politics 23(6). 965-983.

Holliman, Richard. 2004. Media coverage of cloning: A study of media content, production and reception. Public Understanding of Science 13(2). 107-130.

Horst, Maja. 2013. A field of expertise, the organization, or science itself? Scientists' perception of representing research in public communication. Science Communication 35(6). 758-779. 
Ivanova, Ana, Mike S. Schäfer, Inga Schlichting \& Andreas Schmidt. 2013. Is there a medialization of climate science? Results from a survey of German climate scientists. Science Communication 35(5). 626-653.

Jensen, Jakob D. 2008. Scientific uncertainty in news coverage of cancer research: Effects of hedging on scientists' and journalists' credibility. Human Communication Research 34(3). 347-369.

Kahan, Dan M., Ellen Peters, Maggie Wittlin, Paul Slovic, Lisa Larrimore Ouellette, Donald Braman \& Gregory Mandel (2012). The polarizing impact of science literacy and numeracy on perceived climate change risks. Nature Climate Change 2. 732-735.

Kahan, Dan M., Dietram A. Scheufele \& Kathleen H. Jamieson. 2017. Introduction: Why Science Communication? In Kathleen H. Jamieson, Dan M. Kahan \& Dietram Scheufele (eds.), The Oxford handbook on the science of science communication, 1-11. Oxford: Oxford University Press.

Kawamoto, Shishin, Minoru Nakayama \& Miki Saijo. 2011. A survey of scientific literacy to provide a foundation for designing science communication in Japan. Public Understanding of Science. 674-690.

Kessler, Sabrina H. 2016. Das ist doch evident! Eine Analyse dargestellter Evidenzframes und deren Wirkung am Beispiel von TV-Wissenschaftsbeiträgen [It's evident! Identifying frames of evidence as used in science TV programs and testing their effects on beliefs] (Gesundheitskommunikation | Health Communication 12). Baden-Baden: Nomos.

Kessler, Sabrina H. \& Lars Guenther. 2017. Eyes on the frame: Explaining people's online searching behavior in response to TV consumption. Internet Research 27(2). 303-320.

Kessler, Sabrina H. \& Arne F. Zillich. 2018. Searching online for information about vaccination: Assessing the influence of user-specific cognitive factors using eye-tracking. Health Communication. DOI:10.1080/10410236.2018.1465793

Kiernan, Vincent. 2000. The Mars meteorite: A case study in controls on dissemination of science news. Public Understanding of Science 9(1). 15-41.

Knudsen, Susanne. 2005. Communicating novel and conventional scientific metaphors: a study of the development of the metaphor of genetic code. Public Understanding of Science 14(4). 373-392.

Kohring, Matthias, Frank Marcinkowski, Christian Lindner \& Sarah Karis. 2013. Media orientation of German university decision makers and the executive influence of public relations. Public Relations Review 39(3). 171-177.

Kreimer, Pablo, Luciano Levin \& Pablo Jensen. 2011. Popularization by Argentine researchers: the activities and motivations of CONICET scientists. Public Understanding of Science 20(1). 37-47.

Kristiansen, Silje, Mike S. Schäfer \& Sabine Lorencez. 2016. Science journalists in Switzerland: Results from a survey on professional goals, working conditions, and current changes. Studies in Communication Sciences 16(2). 132-140.

Ladle, Richard J., Paul Jepson \& Robert J. Whittaker. 2005. Scientists and the media: the struggle for legitimacy in climate change and conservation science. Interdisciplinary Science Reviews 30(3). 231-240.

LaFollette, Marcel C. 1990. Making science our own. Chicago - public images of science 1910-1950. Chicago: The University of Chicago Press.

Lehmkuhl, Markus \& Hans P. Peters. 2016. Constructing (un-)certainty: An exploration of journalistic decision-making in the reporting of neuroscience. Public Understanding of Science 25(8). 909-926.

Madden, Kelly, Xiaoli Nan, Rowena Briones \& Leah Waks. 2012. Sorting through search results: A content analysis of HPV vaccine information online. Special Issue: The Role of Internet Use in Vaccination Decisions 30(25). 3741-3746.

Maeseele, Pieter. 2009. NGOs and GMOs - A case study in alternative science communication. Javnost-the Public 16(4). 55-72. 
Maibach, Edward W., Deanne Weber, Holly Massett, Gregory R. Hancock \& Simani Price. 2006. Understanding consumers' health information preferences development and validation of a brief screening instrument. Journal of Health Communication 11(8). 717-736.

Marcinkowski, Frank, Matthias Kohring, Silke Fürst \& Andres Friedrichsmeier. 2014. Organizational influence on scientists' efforts to go public: An empirical investigation. Science Communication 36(1). 56-80.

Medvecky, Fabien. 2017. Fairness in knowing: Science communication and epistemic justice. Science and Engineering Ethics. 1-16.

Meier, Klaus \& Frank Feldmeier. 2005. Wissenschaftsjournalismus und Wissenschafts-PR im Wandel [Science journalism and science PR in transition]. Publizistik 50(2). 201-224.

Metag, Julia. 2017. Rezeption und Wirkung öffentlicher Wissenschaftskommunikation [Reception and effect of public science communication]. In Heinz Bonfadelli, Birte Fähnrich, Corinna Lüthje, Jutta Milde, Markus Rhomberg \& Mike Schäfer (eds.), Forschungsfeld Wissenschaftskommunikation, 251-274. Wiesbaden: Springer VS.

Metag, Julia \& Frank Marcinkowski. 2014. Technophobia towards emerging technologies? A comparative analysis of the media coverage of nanotechnology in Austria, Switzerland and Germany. Journalism 15(4). 463-481.

Metag, Julia \& Mike S. Schäfer. 2017. Hochschulen zwischen Social Media-Spezialisten und Online-Verweigerern. Eine Analyse der Online- und Social Media-Kommunikation promotionsberechtigter Hochschulen in Deutschland, Österreich und der Schweiz [Universities between social media specialists and online objectors. An analysis of the online and social media communication of promotion-authorised universities in Germany, Austria and Switzerland]. Studies in Communication / Media 6(2). 160-195.

Metag, Julia \& Mike S. Schäfer (eds.). 2018. Segmentation analyses in science communication. Special Issue of Environmental Communication.

Metcalfe, Jenni \& Toss Gascoigne. 1995. Science journalism in Australia. Public Understanding of Science 4(4). 411-428.

NASW. 2011. About the National Association of Science Writers Inc. https://www.nasw.org/ about-national-association-science-writers-inc (accessed 28 June 2018).

National Science Board. 2016. Science and Engineering Indicators 2016. Arlington, VA: National Science Board.

Nelkin, Dorothy. 1995. Science controversies. The dynamics of public disputes in the United States. In Sheila Jasanoff, Gerald E. Markle, James C. Petersen \& Trevor Pinch (eds.), Handbook of science and technology studies, 444-456. Thousand Oaks, London \& New Delhi: Sage.

Neresini, Federico \& Massimiano Bucchi. 2010. Which indicators for the new public engagement activities? An exploratory study of European research institutions. Public Understanding of Science 20(1). 64-79.

Nisbet, Matthew C., Dietram A. Scheufele, James Shanahan, Patricia Moy, Dominique Brossard \& Bruce V. Lewenstein. 2002. Knowledge, reservations, or promise? Communication Research 29(5). 584-608.

Nisbet, Matthew C., Dominique Brossard \& Adrienne Kroepsch. 2003. Framing science: The stem cell controversy in an age of press/politics. Harvard International Journal of Press/Politics 8(2). 36-70.

Nisbet, Matthew C. \& Dietram A. Scheufele. 2009. What's next for science communication? Promising directions and lingering distractions. American Journal of Botany 96(10). 1767-1778.

Nisbet, Matthew C. \& Declan Fahy. 2015. The need for knowledge-based journalism in politicized science debates. The ANNALS of the American Academy of Political and Social Science 658(1). 223-234. 
Nisbet, Matthew C. \& Ezra Markowitz (eds.). 2016. Science communication research: Bridging theory and practice. Washington, DC: American Association for the Advancement of Science.

OST \& Wellcome Trust. 2000. Science and the public: A review of science communication and public attitudes to science in Britain. London: The Office of Science and Technology (OST) \& Wellcome Trust.

Painter, James, Maria C. Erviti, Richard Fletcher, Candice Howard, Silje Kristiansen, Bienvenido Leon, Alain Ouakrat, Adrienne Russell \& Mike S. Schäfer. 2016. Something old, something new. Digital media and the coverage of climate change. Oxford: Reuters Institute for the Study of Journalism.

Pellechia, Marianne G. 1997. Trends in science coverage: A content analysis of three US newspapers. Public Understanding of Science 6(1). 49-68.

Pennycook, Gordon \& David G. Rand. 2017. The evolution of analytic thought? The Behavioral and Brain Sciences 40. 215.

Peters, Hans P. 1994. Wissenschaftliche Experten in der öffentlichen Kommunikation über Technik, Umwelt und Risiken [Scientific experts in public communication about technology, environment and risks]. In Friedhelm Neidhardt (ed.), Öffentlichkeit, öffentliche Meinung, soziale Bewegungen (Sonderheft 34 der Kölner Zeitschrift für Soziologie und Sozialpsychologie), 162-190. Opladen: Westdeutscher Verlag.

Peters, Hans P., Dominique Brossard, Suzanne de Cheveigné, Sharon Dunwoody, Harald Heinrichs, Arlena Jung, Monika Kallfass, Steve Miller, Imme Petersen, Shoji Tsuchida, Anna Cain \& Anne-Sophie Paquez. 2009. Medialisierung der Wissenschaft und ihre Relevanz für das Verhältnis zur Politik [Medialization of science and its relevance to the relationship to politics]. In Hans P. Peters (ed.), Medienorientierung biomedizinischer Forscher im internationalen Vergleich. Die Schnittstelle von Wissenschaft und Journalismus und ihre politische Relevanz, 9-43. Jülich: Forschungszentrum Jülich.

Poliakoff, Ellen \& Thomas L. Webb. 2007. What factors predict scientists' intentions to participate in public engagement of science activities? Science Communication 29(2). 242-263.

Post, Senja. 2017. Research methods for assessing journalistic decisions, Advocacy strategies, and communication practices related to climate change. In Matthew C. Nisbet, Shirley S. Ho, Ezra Markowitz, Saffron O'Neill, Mike S. Schäfer \& Jagadish Thaker (eds.), Encyclopedia of climate change communication, Online first. New York: Oxford University Press.

Post, Senja \& Michaela Maier. 2016. Stakeholders' rationales for representing uncertainties of biotechnological research. Public Understanding of Science 25(8). 944-960.

Rauchfleisch, Adrian \& Mike S. Schäfer. 2018. Structure and development of science communication research: Co-citation analysis of a developing field. Journal of Science Communication 17(3). $1-21$.

Research Councils UK. 2008. Public attitudes to science 2008: A survey. London: Department of Innovation, Universities \& Skills.

Riesch, Hauke, Clive Potter \& Linda Davies. 2013. Combining citizen science and public engagement: the Open Air Laboratories Programme. Journal of Science Communication 12(3). A03.

Rödder, Simone \& Mike S. Schäfer. 2010. Repercussion and resistance: An empirical study in the interrelation between science and mass media. Communications 35(3). 249-267.

Ruhrmann, Georg, Lars Guenther, Sabrina H. Kessler \& Jutta Milde. 2015. Frames of scientific evidence: How journalists represent the (un)certainty of molecular medicine in science television programs. Public Understanding of Science 24(6). 681-696.

Schäfer, Mike S. 2009. From public understanding to public engagement: An empirical assessment of changes in science coverage. Science Communication 30(4). 475-505.

Schäfer, Mike S. 2011. Sources, characteristics and effects of mass media communication on science: A review of the literature, current trends and areas for future research. Sociology Compass 5(6). 399-412. 
Schäfer, Mike S. 2012a. Online communication on climate change and climate politics: a literature review. Wiley Interdisciplinary Reviews-Climate Change 3(6). 527-543.

Schäfer, Mike S. 2012b. Taking stock: a meta-analysis of studies on the media's coverage of science. Public Understanding of Science 21(6). 650-663.

Schäfer, Mike S. 2014. The media in the labs, and the labs in the media: What we know about the mediatization of science. In Knut Lundby (ed.), Mediatization of communication. Vol. 21 of the Handbook of Communication Sciences, 571-594. Berlin: de Gruyter Mouton.

Schäfer, Mike S. 2015. Climate change in the media. In James D. Wright (ed.), International encyclopedia of the social \& behavioral sciences, 2nd edition 3853-859. Oxford: Elsevier.

Schäfer, Mike S. 2017a. How changing media structures are affecting science news coverage. In Kathleen H. Jamieson, Dan M. Kahan \& Dietram Scheufele (eds.), The Oxford handbook on the science of science communication, 51-60. Oxford: Oxford University Press.

Schäfer, Mike S. 2017b. Wissenschaftskommunikation Online [Science communication online]. In Heinz Bonfadelli, Birte Fähnrich, Corinna Lüthje, Jutta Milde, Markus Rhomberg \& Mike S. Schäfer (eds.), Forschungsfeld Wissenschaftskommunikation, 275-293. Wiesbaden: Springer vS.

Schäfer, Mike S., Silje Kristiansen \& Heinz Bonfadelli. 2015. Wissenschaftskommunikation im Wandel: Relevanz, Entwicklung und Herausforderungen des Forschungsfeldes [Science communication in transition: relevance, development and challenges of the research field]. Wissenschaftskommunikation im Wandel. 10-42.

Schäfer, Mike S. \& Saffron O'Neill. 2017. Frame analysis in climate change communication. In Matthew C. Nisbet, Shirley S. Ho, Ezra Markowitz, Saffron O'Neill, Mike S. Schäfer \& Jagadish Thaker (eds.), Encyclopedia of climate change communication, Online first. New York: Oxford University Press.

Schäfer, Mike S., Tobias Füchslin, Julia Metag, Silje Kristiansen \& Adrian Rauchfleisch. 2018. The different audiences of science communication. A segmentation analysis of the Swiss population's perceptions of science and their information and media use patterns. Public Understanding of science 27(7). 836-856.

Scheufele, Dietram A., Kathleen H. Jamieson \& Dan M. Kahan. 2017. Conclusion - On the horizon: The changing science communication environment. In Kathleen H. Jamieson, Dan M. Kahan \& Dietram Scheufele (eds.), The Oxford handbook on the science of science communication, 461-467. Oxford: Oxford University Press.

Schiele, Bernard. 2008. Science museums and science centres. In Massimiano Bucchi \& Brian Trench (eds.), Handbook of public communication of science and technology, 27-40. London: Routledge.

Serong, Julia, Lars Koppers, Edith Luschmann, Alejandro M. Ramirez, Kristian Kersting, Jörg Rahnenführer \& Holger Wormer. 2017. Öffentlichkeitsorientierung von Wissenschaftsinstitutionen und Wissenschaftsdisziplinen: Eine Längsschnittanalyse des "Informationsdienstes Wissenschaft" (idw) [Public orientation of science institutions and scientific disciplines: A longitudinal analysis of the "Informationsdienst Wissenschaft" (idw)] 1995-2015. Publizistik 62(2). 153-178.

Slovic, Paul (ed.). 2010. The feeling of risk: New perspectives on risk perception. London: Routledge.

Stocking, Holly S. \& Lisa W. Holstein. 2009. Manufacturing doubt: journalists' roles and the construction of ignorance in a scientific controversy $10.1177 / 0963662507079373$. Public Understanding of Science 18(1). 23-42.

Summ, Annika \& Anna-Maria Volpers. 2016. What's science? Where's science? Science journalism in German print media. Public Understanding of Science 25(7). 775-790.

Sumner, Petroc, Solveiga Vivian-Griffiths, Jacky Boivin, Andy Williams, Christos A. Venetis, Aimée Davies, Jack Ogden, Leanne Whelan, Bethan Hughes, Bethan Dalton, Fred Boy \& Christopher 
D. Chambers. 2014. The association between exaggeration in health related science news and academic press releases: retrospective observational study. British Medical Journal 349.

Trench, Brian \& Massimiano Bucchi. 2010. Science communication, an emerging discipline: Road maps for the 21st century research in science communication. Journal of Science Communication 9(3). C01.

Trench, Brian, Massimiano Bucchi, Latifah Amin, Gultekin Cakmakci, Bankole A. Falade, Arko Olesk \& Carmelo Polino. 2014. Global spread of science communication. In Massimiano Bucchi \& Brian Trench (eds.), Handbook of public communication of science and technology, 2nd edn., 214-230. London: Routledge.

van der Sanden, Maarten C.A. \& Brian Trench. 2010. Analysis of doctoral research in science communication. Science Communication without Frontiers: Proceedings of 11th International Conference on Public Communication of Science and Technology. 92-95.

Varner, Johanna. 2014. Scientific outreach: Toward effective public engagement with biological science. Bioscience 64(4). 333-340.

Weigold, Michael F. 2001. Communicating science. A review of the literature. Science Communication 32(2). 164-193.

Weingart, Peter (ed.). 2005. Die Wissenschaft der Öffentlichkeit. Essays zum Verhältnis von Wissenschaft, Medien und Öffentlichkeit [The science of the public. Essays on the relationship between science, the media and the public]. Weilerswist: Velbrück.

Weingart, Peter, Christian Salzmann \& Stefan Wörmann. 2006. Die gesellschaftliche Einbettung der Biomedizin: Eine Analyse der deutschen Mediendiskurse [The Social Embedding of Biomedicine: An Analysis of German Media Discourses]. In Marc-Denis Weitze \& Wolf-Andreas Liebert (eds.), Kontroversen als Schlüssel zur Wissenschaft? Wissenskulturen in sprachlicher Interaktion, 95-112. Bielefeld: transcript.

Wilkins, John S. 2008. The roles, reasons and restrictions of science blogs. Trends in Ecology \& Evolution 23(8). 411-413.

Wilson, Kris M. 2000. Drought, debate, and uncertainty: Measuring reporters' knowledge and ignorance about climate change. Public Understanding of Science 9(1). 1-13.

Yearley, Steven. 2014. Environmentalists as communicators of science. In Massimiano Bucchi \& Brian Trench (eds.), Handbook of public communication of science and technology, 2nd edn., 113-124. London: Routledge.

Zavestoski, Stephen, Stuart Shulman \& David Schlosberg. 2006. Democracy and the environment on the Internet: Electronic citizen participation in regulatory rulemaking. Science, Technology \& Human Values 31(4). 383-408. 